Lindström, JAN - MASchler, YAel Pekarek Doehler, Simona (toim.) 2016: Grammar and negative epistemics in talk-in-interaction. Cross-linguistic studies. - Journal of Pragmatics 106 S.72-2O2.

Linell, Per 2005: The written language bias in linguistics. Its nature, origins and transformations. London: Routledge.

Ochs, Elinor - Schegloff, Emanuel Thompson, SANDra (toim.) 1996: Interaction and grammar. Studies in interactional sociolinguistics 13. Cambridge: Cambridge University Press. https://doi. org/10.1017/CBO9780511620874.

Schegloff, Emanuel - Ochs, Elinor - Thompson, SANDra 1996: Intro- duction. - Elinor Ochs, Emanuel A. Schegloff \& Sandra Thompson (toim.), Interaction and grammar. Studies in interactional sociolinguistics $13 \mathrm{~s}$. 1-51. Cambridge: Cambridge University Press. https://doi.org/10.1017/ CBO9780511620874.001.

Selting, Margret - Couper-Kuhlen, Elizabeth (toim.) 2001: Studies in interactional linguistics. Amsterdam: John Benjamins. https://doi.org/10.1075/ sidag.10.

TANAKA, Нівоко 1999: Turn-taking in Japanese conversation. A study in grammar and interaction. Amsterdam: John Benjamins. https://doi.org/10.1075/pbns.56.

\title{
Tuntevasti Suomessa puhutuista kielistä ja kielitietoisuudesta
}

\begin{abstract}
Mari Honko \& Sanna Mustonen (toim.): Tunne kieli. Matka maailman kieliin ja kielitietoisuuteen. Helsinki: Finn Lectura 2018. 474 s. ISBN 978-951-792-923-3.
\end{abstract}

"Kielitietoisessa koulussa kaikki opiskeltavat kielet ja oppilaiden äidinkielet näkyvät luontevasti. Kielitietoiset työtavat edellyttävät opettajien yhteistyötä. Koulussa tulee luoda yhteistyölle rakenteet ja toimintaedellytykset." Näin todetaan Opetushallituksen Kielitietoinen opetus kielitietoinen koulu -julkaisussa (KOKK 2017: 7). Monikielisyyttä ja äidinkielistä identiteettiä riittävästi tukemalla voidaan helpottaa uuden kielen oppimista ja opinnoissa menestymistä. Mari Hongon ja Sanna Mustosen toimittama teos Tunne kieli: Matka maailman kieliin ja kielitietoi- suuteen tekee näkyväksi nyky-Suomessa puhuttavien kielten kirjoa. Teos pyrkii lisäämään kielitietoisuutta ja tarjoamaan monikielisyydestä yleistajuista tietoa opettajille ja muille monikielisissä yhteisöissä työskenteleville.

Hongon ja Mustosen teoksella on varsin kunnianhimoiset tavoitteet. Teoksessa tutustutaan diversiteetin, kielitietoisuuden ja kielitiedon käsitteisiin, monikielisyyden muotoihin sekä vertaillaan Suomessa puhuttavia vähemmistökieliä suomen kieleen. Käsiteltävinä ovat arabian, bengalin, kiinan, kurdin, persian, romanian, somalin, tagalogin, thain, turkin, venäjän, vietnamin ja viron kielet. Johdannossa hahmotellaan kohdeyleisöksi monikielisissä ympäristöissä työskentelevät opettajat, varhaiskasvattajat ja kieli- 
asiantuntijat sekä sellaisiksi opiskelevat. Tarvetta tämän tyyppiselle teokselle on, sillä nyky-Suomessa puhuttavien kielten tilannetta ei ole aiemmin tarkasteltu näin laajasti. Teos on kirjoitettu ensi sijassa opetuksen tueksi, mutta kuten tekijät muistuttavat, "[m]onikielisyys on läsnä jokaisen arjessa" (s. 9). Kokoelman julkaisemisen yhteiskunnallinen tarve kuvataan vakuuttavasti.

Teosta täydentää kustantajan verkkosivustolla avoimesti saatavilla oleva lisämateriaali, johon sisältyy muun muassa teksti- ja ääniesimerkkejä kokoelmassa esiteltyjen kielten sanastosta ja fraaseista sekä suomen kieltä esittelevä yleistajuinen teksti jokaisella kokoelman kielellä.

Tunne kieli on hankejulkaisu, joka on syntynyt Koneen Säätiön rahoittaman Vertailusta voimaa -hankkeen (20162017) tuotteena. Kirjoittajat ovat kielitieteilijöitä, kääntäjiä ja opettajia. Useimmat vähemmistökieliä esittelevien artikkelien kirjoittajista ovat kielten natiiveja puhujia.

\section{Rikas, raskas kokonaisuus}

Teos on runsas, lähes 500-sivuinen lukupaketti, joka jakautuu kahteen laajaan osaan. Kokoelman aloittaa viiden johdantoluvun kokonaisuus (s. 18-161), jota seuraa 13 kielikohtaista artikkelia (s. 164450). Johdantoluvuissa taustoitetaan ja avataan teoksen keskeisiä käsitteitä ja näkökulmia, esitellään maailman kielten piirteitä ja kirjoitusjärjestelmiä sekä kuvataan suomen kielen erilaisuutta ja samanlaisuutta verrattuna muihin kieliin. Johdantoluvuilla on selkeästi rajatut teemat, vaikkakin ensimmäisen ja toisen luvun välillä on jonkin verran toisteisuutta. Viimeinen johdantoluku, toimittajien kirjoittama "Vertailusta voimaa" (s. 143-161), tarjoaa lukuohjeita toisen osan kieliartikkeleihin, mistä syystä luvun olisi voinut luontevasti sijoittaa myös toisen osan alkuun. Jokainen kieliartikkeli kuvaa yhtä
Suomessa puhuttavaa vähemmistökieltä. Kokonaisuutena teoksen jäsennys on selkeä ja toimiva.

Johdantolukujen ja kieliartikkelien lisäksi teokseen sisältyy esipuhe, lyhenneja sanaluettelot, äännetaulukot, seikkaperäinen kokoelman sisällön kuvaus, kirjoittajien esittelyt ja kiitokset sekä lähteet. Osa näistä oheisteksteistä on teoksen alussa, osa lopussa. Ratkaisu on tuonut muutoinkin sivumäärältään runsaaseen kokoelmaan tarpeetonta toistoa. Esimerkiksi teoksen tavoitteet esitellään sekä esipuheessa että "Materiaalin sisältö" -jaksossa. Niin ikään lyhenteitä selitetään lyhenneluettelon lisäksi toisessa johdantoluvussa.

Kokoelman johdantolukuihin liittyy pohdintatehtäviä ja harjoituksia. Toimittajat kannustavat (s. 9) kokeilemaan ja soveltamaan tehtäviä erilaisten ryhmien ja tilanteiden tarpeisiin. Lukijalle jää kuitenkin epäselväksi, kenelle ja millaisiin yhteyksiin tehtävät on suunnattu. Varsinkin kielenoppijalle, jolla ei ole kielitieteellistä koulutusta, monet tehtävät saattavat olla liian haastavia. Sinänsä tehtävät ovat ajattelua herätteleviä ja siten kielitietoisia toimintatapoja tukevia, mutta kohderyhmä tuntuu jääneen hahmottamatta. Teoksen laajuuden huomioiden näiden tehtävien sopivampi paikka olisi ollut painetun kirjan sijaan verkkomateriaalissa.

Taitto on toteutettu niin, että lukujen väliset siirtymät on helppo paikantaa. Kieliartikkelien tekstit on jäsennetty numeroituihin lukuihin, joissa on myös ohjaavia väliotsikoita. Selkeän otsikoinnin ansiosta tiedonhaku kieliartikkeleista sujuu vaivattomasti. Johdantoluvuissa ei ole käytetty numeroituja alalukuja, ja eritasoisten otsikoiden taitto ei ole niin selkeää, että silmäileväkin lukija ymmärtäisi välittömästi, milloin on kyse ylemmän, milloin alemman tason otsikosta. Teksti on taitettu kautta linjan todella tiiviisti, jopa tukkoisesti. 


\section{Suomi maailman kielten joukossa}

Teoksen toimittajat ovat kirjoittaneet teoksen ensimmäisen, neljännen ja viidennen johdantoluvun. Ensimmäinen luku "Kielistä kielitaitoon" tarjoaa lukijalle hyvän yleiskuvan teoksen fokuksesta ja avainkäsitteistä, mikä auttaa siirryttäessä seuraaviin lukuihin. Luvussa avataan erityisesti yksi-, kaksi- ja monikielisyyden sekä ensi- ja äidinkielen käsitteitä. Suomen ja maailman kielten tilannetta kuvataan esimerkiksi Tilastokeskuksen ja Ethnologuen julkaisemien tilastotietojen avulla. Kielitilanne on jatkuvassa muutoksessa, ja tämän luvun tilastotiedot ovat herkästi vanhenevia, mutta ilmestymisaikanaan tekijät onnistuvat välittämään ajantasaisen kuvan monikielisestä Suomesta ja suomalaisesta monikielisyydestä.

Yrjö Laurannon kirjoittama kakkosluku "Kielten kirjoa, suomen sävyjä" on kokoelman laajin osa $(63$ s.). Lauranto aloittaa esittelemällä lukijalle kielen erilaiset alakäsitteet (mm. luonnollinen kieli, enemmistö- ja vähemmistökieli, äidinkieli, ensikieli ja kotikieli), minkä jälkeen hän tarkastelee kielten elinkaarta sekä rakenteellisia eroja ja yhtäläisyyksiä typologisesta näkökulmasta. Rakenne-eroja konkretisoidaan hyvin valituilla ja glossatuilla esimerkkilauseilla eri kielistä. Ilahduttavaa on, että tarkasteltavien piirteiden joukkoon on valikoitunut myös keskustelupuheelle tyypillisiä ilmiöitä, esimerkiksi vuorovaikutuspartikkelien käyttö ja prosodia. Lauranto nostaa esiin myös sen, miten kielisukulaisuus vaikuttaa kielenoppimiseen.

Tommi Nieminen kuvaa luvussa "Kirjoittaminen ja kirjoitusjärjestelmät" puheen ja kirjoituksen eroja sekä maailman kielten kirjoitusjärjestelmiä. Niemisen teksti tarjoaa hauskoja ja havainnollisia esimerkkejä erilaisten kirjoitusjärjestelmien toimintaperiaatteista suomen kirjoitusjärjestelmään verrattuna, mutta yhteys teoksessa käsiteltäviin kieliin jää konkre- tisoimatta. Nieminen esittelee yleistajuisesti fonografisen ihanteen eli sen, että kielen kutakin foneemia edustaa yksi grafeemi ja päinvastoin, ja tuo esiin, että suomi muutamin poikkeuksin noudattaa tätä periaatetta.

Mustosen ja Hongon laatima luku "Monikielisyyttä tukeva pedagogiikka" palaa teoksen alussa määriteltyihin tavoitteisiin ja tarkastelee kielitietoisuutta ja kielenoppimista pedagogiikan näkökulmasta. Kirjoittajat pohtivat, millainen taito monikielisyys on ja miten esimerkiksi kouluissa voidaan toimia monikielisyyttä tukevalla tavalla. Mustonen ja Honko kuvaavat vakuuttavasti kieli- ja kielenoppimiskäsityksissä parhaillaan tapahtuvaa globaalia muutosta, joka ilmenee esimerkiksi siirtolaisuutena ja teknologian kehityksenä ja jonka seurauksena yksikielisyyden ideologia on murenemassa ja monikielisyys on kehittymässä uudeksi normiksi. Martin (2016) on osuvasti nimittänyt tähän liittyviä ilmiöitä, kuten käyttöpohjaisten kielikäsitysten nousua sekä kielenoppimisen ja monikielisyyden tutkimuksen lähentymistä, lingvistiseksi käänteeksi.

Viimeinen johdantoluku on Hongon ja Mustosen kirjoittama "Vertailusta voimaa", joka, kuten aiemmin mainitsin, toimii kieliartikkelien johdantona. Tämä luku sisältää sinänsä kiinnostavaa The world atlas of language structures -tietokantaan (WALS) perustuvaa tietoa kielten rakenteista sekä ohjeita kielten vertailuun. Toisaalta sen sisältö näyttäytyy osin edellisten johdantolukujen toistona. Sananlaskujen erikielisten toisintojen esittelyllä kirjoittajat ovat luultavasti halunneet korostaa, että perusmerkitykset toistuvat eri kielissä melko samanlaisina, vaikka sananlaskujen sisältö on kieli- ja kulttuurisidonnaista. Käsittely olisi kuitenkin voinut olla tiiviimpää, ja kenties WALS-vertailut ja sananlaskukokoelmat olisivat toimineet paremmin teosta täydentävänä verkkomateriaalina. 


\section{Suomen monet kielet}

Kokoelman toisen osion muodostavissa kieliartikkeleissa syvennytään Suomessa puhuttaviin vähemmistökieliin. Kokoelman alussa toimittajat esittävät (s. 10), että teokseen valitut kielet ovat Suomen puhutuimpia maahanmuuttajakieliä lukuun ottamatta bengalia ja tagalogia, jotka on otettu mukaan sillä perusteella, että ne ovat paljon puhuttuja kieliä kansainvälisesti. Pois on jätetty ne maahanmuuttajakielet, joista on jo runsaasti oppimateriaalia (mp.). Tekijät eivät kuitenkaan mainitse, mitä nämä kielet ovat. Lukija voi päätellä, että käsittelyn ulkopuolelle on rajattu ainakin englanti. Toisaalta venäjä ja viro ovat kokoelmassa mukana, vaikka niistä materiaalia on helposti saatavilla. Sen sijaan albaniaa ei kokoelmassa käsitellä, vaikka se on Suomessa puhuttujen kielten kärkikymmenikössä. Rajauksen perusteluissa on siis hieman epäloogisuutta. Tästä huolimatta kokoelmaan valitut kielet muodostavat monipuolisen ja melko tasapainoisen kokonaisuuden. Kielet ovat rakenteiltaan ja kirjoitusjärjestelmiltään erilaisia, mikä korostaa kokoelman päätavoitetta, kielitietoisuuden ja kielitiedon lisäämistä.

Kieliartikkelit ovat 15-25-sivuisia, ja niiden rakenne on yhtenäinen ja helposti seurattava. Jokainen artikkeli alkaa yleisesittelyllä, jossa käydään tiiviisti läpi kielen nykytilanne ja status, kielen pääkehitysvaiheet, puhuma-alueet ja puhutun kielen variaatio, kirjoitusjärjestelmä ja kirjoitetun kielen tilanne. Seuraavaksi esitellään sanastoa, fonologiaa, morfologiaa, morfosyntaksia ja syntaksia. Tarkasteltavat kielet ovat rakenteiltaan erilaisia, ja siksi artikkelienkin painotuksissa on eroja, mikä on vain hyvä asia. Kielestä riippumatta esimerkkien ääntäminen on osoitettu yhtenäisellä tavalla, IPA-järjestelmän foneettisen aakkoston mukaisesti. Kieliartikkeleissa keskitytään kielitiedon välittämiseen, mutta kielenkäytön käsittely jää vähäisemmäksi.

Kieliartikkelien lopussa olevat, kohdekielellä kirjoitetut ja kopiointioikeudelliset sivut ovat kokoelman konkreettisinta antia. "Helppoa ja erilaista" -sivu tarjoaa kohdekielen ja suomen vertailun tiiviissä muodossa. "Yhden kielen sijaan monta" -sivu (käännöspohja suomeksi s. 28) perustuu Daghettin, Latomaan ja Shamekhin (2012) esitykseen. Tämä sivu on kaikissa kieliartikkeleissa samansisältöinen, ja se käsittelee monikielisyyttä ja oman äidinkielen merkitystä. Kohdekielellä kirjoitetut sivut toimivat työkaluina, joiden avulla monikielisen ryhmän varhaiskasvattaja tai opettaja voi lisätä oppijan tai tämän vanhempien kielitietoa.

\section{Kirkas kannanotto}

Tunne kieli onnistuu hyvin tavoitteissaan. Kokoelma ja siihen liittyvä verkkomateriaali tarjoavat koulutuksen ja kasvatuksen ammattilaisille runsaasti tietoa kielitietoisuudesta ja kielistä sekä konkreettisia välineitä monikielisten oppijoiden kohtaamiseen ja kielitietoisten toimintatapojen kehittämiseen ja ylläpitämiseen.

Teos on perusteellinen. Rakenteen osittaisesta epäloogisuudesta ja toisteisuudesta sekä paikoin tukkoisesta taitosta huolimatta kokoelman tekstit on kirjoitettu ymmärrettävästi ja kohdelukijakunta huomioiden. Tarpeetonta terminologiaa on vältetty, hakutermit on lihavoitu ja määritelty ja lyhenteet selitetty. Niin kieliartikkelit kuin melkein kaikki johdantoluvutkin toimivat itsenäisesti luettuina, mikä mahdollistaa niiden hyödyntämisen esimerkiksi yliopistojen kurssikirjallisuutena.

Tunne kieli ei ole pelkkä deskriptiivinen kuvaus suomen ja maahanmuuttajakielten nykytilanteesta, vaan toimittajat tekevät monessa yhteydessä yhteiskunnallisia kannanottoja. Esimerkiksi sivulla 13 he esittävät: 
Päiväkoti ja koulu ovat keskeisiä yhteiskunnallisia instituutiota, joilla on valta tehdä kieliä näkyviksi ja antaa niille tunnustettu asema. Juuri näissä yhteisöissä ja instituutioissa olisi tärkeää löytää toimintaan kriittinen näkökulma, joka mahdollistaisi erilaisten hierarkioiden ja vaientamisten näkyväksi tekemisen: miten eri kielistä ja erikielisistä puhutaan, miten niiden käyttöön suhtaudutaan ja kuka niitä saa käyttää.

Tunne kieli -teoksella on haluttu välittää kielipoliittisesti ja laajemminkin yhteiskunnallisesti ajankohtainen sanoma, ja kokonaisuus onnistuu tässä tehtävässä mielestäni hyvin ja kannanotto kuuluu kirkkaana. Kokoelma on ensisijaisesti suunnattu monikielisissä yhteisöissä työskenteleville, mutta toivoisin teoksen tavoittavan myös koulutusta suunnittelevat ja johtavat henkilöt. Kuten Opetushallitus (KOKK 2017: 7) on linjannut: " - - kielitietoista toimintakulttuuria ei synny ilman kielitietoista johtamista".
Mila KartTunen

etunimi.sukunimi@xamk.fi

Kirjoittaja on valmistunut filosofian tohtoriksi Itä-Suomen yliopistosta

ja toimii suomen kielen ja viestinnän lehtorina Kaakkois-Suomen ammattikorkeakoulussa.

\section{Lähteet}

Daghetti, Rosa - LatomaA, Sirkku

- Shamekhi, Mohammad-Reza

2012: Monikielisyys - arvokas voimavara. Neuvoja perheille. Tampere: Kielten mosaiikki ry.

KOKK = Kielitietoinen opetus - kielitietoinen koulu 2017. Opetushallitus 4:2017. Helsinki: Opetushallitus 2017. http://edu.fi/ download/186995_Kielitietoinen_opetus_verkko.pdf (1.4.2019).

Martin, Maisa 2016 Monikielisyys muutoksessa. - Kieli, koulutus ja yhteiskunta 7(5). https://www.kieliverkosto.fi/ fi/journals/kieli-koulutus-ja-yhteiskuntalokakuu-2016/monikielisyys-muutoksessa (1.4.2019). 